\title{
Clinical Factors Affecting the Costs of Hospitalized Chronic Obstructive Pulmonary Disease Exacerbations
}

Expenses in the diagnosis and treatment of chronic obstructive pulmonary disease (COPD) are observed to be high when the economic consequences of the disease, loss in the labor force, premature death, and familial expenses made due to the illness are taken into account. Expenses in the diagnosis and treatment constitute the direct costs, whereas the economic consequences of the disease, loss in the labor force, premature death, and familial expenses made due to the illness constitute the indirect cost. Also, chronic obstructive pulmonary disease attacks increase costs especially by causing premature deaths. Chronic obstructive pulmonary disease attacks constitute approximately $60 \%$ of the direct costs spent towards COPD. Therefore, one of the most important treatment goals of COPD disease in guidelines and strategy reports is to reduce the attacks.

Considering that the global cost caused by chronic obstructive pulmonary disease currently is approximately $\$ 2.1$ trillion, that $60 \%$ of the direct cost in this comes from COPD attacks, and that this cost is expected to rise to approximately $\$ 4.8$ trillion by the year 2030 , it is all the more essential to reduce the attacks (1).

In the article, "Clinical factors affecting the treatment costs of the cases hospitalized due to exacerbations," printed in this issue of the journal, hospital costs in COPD patients admitted to and treated in the clinic were retrospectively calculated (2). Patients that had been admitted to intensive care were excluded from the study. Winter seasons, where chronic obstructive pulmonary disease attacks are frequent, were selected on purpose, and the total costs in the diagnosis and treatment during hospitalization were taken into consideration. In the study, total cost was calculated as hospital bed fee, the cost of the medicine used during hospitalization, and the cost of the diagnostic (radiological examination, microbiology, and biochemical) examinations.

In the study, the most significant cause in raising the cost was found to be the existence of at least one comorbidity in $47.7 \%$ of the patients. The most important of these comorbidities were cardiovascular (24.5\%) problems, which also included hypertension. The author' explanation of pneumonia as a comorbidity is a problem that causes hesitation in the study. Pneumonia is counted among the causes of attack in studies and reviews that evaluate the causes of attack $(3,4)$. Therefore, it will be appropriate for the author to calculate the cost in patients with comorbidities by excluding pneumonia from the comorbidities. It is the cost of the antibiotics that will determine the cost in patients with pneumonia. An increase in the number of comorbidities also increases the cost, which is to be expected if you take the literature into account.

For the administration of antibiotics, the authors used the Anthonisen criteria. The relationship between cost and severity could also have been calculated in patients in whom the authors determined the severity of the attack by the Anthonisen criteria.

The author stated that they performed spirometry during admission in patients who were admitted with attack complaints. Spirometry during an attack is difficult and may not yield healthy results.

The properties of the hospital in which the study was conducted should also have been mentioned in the methodology of the study. The study demonstrates that the COPD attack costs in Turkey are high; for this reason alone, strategies that clinically and statistically reduce future risk should be prioritized in the stable period treatment.

\section{Nurhayat Yıldırım}

Department of Chest Diseases, İstanbul University Cerrahpaşa Medical School, İstanbul

Address for correspondence: Nurhayat Yıldırım, Department of Chest Diseases, İstanbul University Cerrahpaşa Medical School, İstanbul, Turkey E-mail: nurhayatyil@hotmail.com 
Received date: 29.09 .2014

Accepted date: 29.09 .2014

Available Online Date: 02.12.2014

(c) Copyright 2014 Turkish Respiratory Society (TRS)

DOI: 10.5152/ejp.2014.96630

- Available online at www.eurasianjpulmonol.com

\section{REFERENCES}

1. Bloom DE, Cafiero ET, Jané-Llopis E, Abrahams-Gessel S, Bloom LR, Fathima $\mathrm{S}$, et al. The global economic burden of non-communicable diseases: a re- port by the World Economic Forum and the Harvard School of Public Health, September 2011. Geneva, Switzerland: World Economic Forum. 2011

2. Emre JÇ, Özdemir Ö, Baysak A, Aksoy Ü, Özdemir P, Öz AT, et al. Clinical factors affecting the costs of hospitalized chronic obstructive pulmonary disease exacerbations. Eurasian J Pulmonol 2014; 16: 180-3.

3. Kaya A. Kronik obstrüktif akciğer hastalığında atak ve tedavisi. Eds Umut $S$, Erdinç E. TTD yayınıdır. Galenos Yayıncılık, Ankara, 2008;193-205.

4. Süerdem M. KOAH'ta atak ve tedavisi. Eds Umut S, Yıldırım N. IÜ Cerrahpaşa Tıp Fakültesi Göğüs Hastalıkları Anabilim Dalı Kitapları Serisi, Turgut Yayıncilık ve Ticaret A. Ş. İstanbul 2005;146-60. 